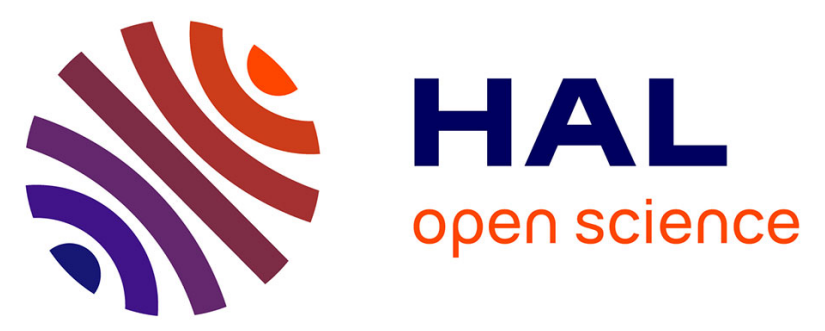

\title{
Deciphering the interactions between the Bacillus cereus linear plasmid, pBClin15, and its host by high-throughput comparative proteomics
}

\author{
Jean-Paul Madeira, Helene Omer, Beatrice Alpha-Bazin, J. Armengaud, \\ Catherine Duport
}

\section{To cite this version:}

Jean-Paul Madeira, Helene Omer, Beatrice Alpha-Bazin, J. Armengaud, Catherine Duport. Deciphering the interactions between the Bacillus cereus linear plasmid, pBClin15, and its host by high-throughput comparative proteomics. Journal of Proteomics, 2016, 146, pp.25-33. 10.1016/j.jprot.2016.06.022 . hal-02637894

\section{HAL Id: hal-02637894 \\ https://hal.inrae.fr/hal-02637894}

Submitted on 28 May 2020

HAL is a multi-disciplinary open access archive for the deposit and dissemination of scientific research documents, whether they are published or not. The documents may come from teaching and research institutions in France or abroad, or from public or private research centers.
L'archive ouverte pluridisciplinaire HAL, est destinée au dépôt et à la diffusion de documents scientifiques de niveau recherche, publiés ou non, émanant des établissements d'enseignement et de recherche français ou étrangers, des laboratoires publics ou privés. 


\title{
Deciphering the interactions between the Bacillus cereus linear plasmid, pBClin15, and its host by high-throughput comparative proteomics
}

\author{
Jean-Paul Madeira a,b, Hélène Omer ${ }^{\mathrm{a}, \mathrm{b}}$, Béatrice Alpha-Bazin ${ }^{\mathrm{b}}$, Jean Armengaud ${ }^{\mathrm{b}}$, Catherine Duport ${ }^{\mathrm{a}, *}$ \\ a SQPOV, UMR0408, Avignon Université, INRA, F-84914 Avignon, France \\ ' CEA, DSV, IBiTec-S, SPI, Li2D, Laboratory “Innovative technologies for Detection and Diagnostics", Bagnols-sur-Cèze F-30200, France
}

Keywords:

Proteome

Bacillus cereus

Plasmid

Prophage

Shotgun proteomics

\begin{abstract}
A B S T R A C T
The pathogen, Bacillus cereus, is able to adapt its metabolism to various environmental conditions. The reference strain, Bacillus cereus ATCC 14579, harbors a linear plasmid, pBClin15, which displays a cryptic prophage behavior. Here, we studied the impact of pBClin 15 on the aerobic respiratory metabolism of $B$. cereus by curing its host strain. We compared, by means of a high-throughput shotgun proteomic approach, both the cellular proteome and the exoproteome of B. cereus ATCC 14579 in the presence and absence of pBClin15 at the early, late and stationary growth phases. The results were visualized through a hierarchical cluster analysis of proteomic data. We found that $\mathrm{pBClin} 15$ contributes significantly to the metabolic efficiency of $B$. cereus by restricting the production of chromosome-encoded phage proteins in the extracellular milieu. The data also revealed intricate regulatory mechanisms between pBClin 15 and its host. Finally, we show that pBClin 15 provides benefit to its host to adapt to different ecologic niches.

Biological significance: Bacteria belonging to the Bacillus cereus group include B. cereus, a notorious food borne pathogen which causes gastroenteritis. The B. cereus type, strain ATCC 14579 , harbors a linear plasmid, pBClin15, which displays cryptic prophage behavior. Here, we present data supporting the idea that pBClin 15 may have a much greater role in B. cereus metabolism that has hitherto been suspected. Specifically, our comparative proteomic analyses reveal that pBClin 15 manages $B$. cereus central metabolism to optimize energy and carbon utilization through the repression of several chromosome-encoded phage proteins. These results suggest that pBClin15 provides benefit to the host for surviving adverse environmental conditions.
\end{abstract}

\section{Introduction}

Members of the Bacillus cereus sensu lato group are found in diverse environments and include eight closely related species - Bacillus cereus sensu stricto, Bacillus anthracis, Bacillus thuringiensis, Bacillus weihenstephanensis, Bacillus mycoides, Bacillus pseudomycoides, Bacillus cytotoxicus, and Bacillus toyonensis [1,2]. The plasmids in this group display a strain-dependent distribution, with some strains containing no plasmid, whereas others have many. Some of these plasmids have a small genome size, only $2 \mathrm{~kb}$, whereas others are very large, up to $600 \mathrm{~kb}$ [3]. Large plasmids are key components in defining the phenotypic traits associated with pathogenesis [4]. For example, emetic syndrome, which is associated with B. cereus sensu stricto, is caused by cereulide. The cereulide synthetase gene cluster, which encodes the enzymatic machinery required for the biosynthesis of cereulide, is located on a $208 \mathrm{~kb}$ megaplasmid [5]. As a mammalian pathogen, the ability of $B$. anthracis to cause anthrax originates from two large plasmids: pXO1

* Corresponding author at: UMR SQPOV, INRA PACA, 228, Route de l'Aérodrome, CS 40509, Domaine Saint Paul-Site Agroparc, 84914 Avignon Cedex 9, France.

E-mail address: catherine.duport@univ-avignon.fr (C. Duport).
(181.6 kb) that encodes the tripartite lethal toxin complex and pXO2 $(93.5 \mathrm{~kb})$, which contains the biosynthetic genes for the poly- $\gamma$-Dglutamic acid capsule [6]. B. thuringiensis forms crystal-like parasporal inclusions during sporulation [7-9]. These inclusions contain $\delta$-endotoxins with insecticidal properties. Most of the genes (cry) encoding these toxins are located on large plasmids [10]. Whereas the role of large plasmids in pathogenesis is well defined, the function of the other plasmids in the group is relatively unknown.

The $B$. cereus type, strain ATCC 14579, harbors a 15,274 bp linear plasmid, pBClin15, which displays cryptic prophage behavior [11-13]. The genetic structure of pBClin15 is reminiscent of temperate phages belonging to the Tectiviridae family. This family includes the bacteriophages, Bam35, GIL01 and GIL16 from B. thuriengensis and AP50 from $B$. anthracis [13-18]. The $\mathrm{pBClin} 15$ genome contains 28 open reading frames (ORFs) [17]. Some of these ORFs encode proteins involved in phage genome replication and regulation, virion structure and DNA packaging [17,19], but the function of many is so far undocumented. One of these ORFs, namely ORF2, encodes a protein (Bcp0002) that displays binding properties towards DNA fragments of both chromosomal and plasmid origin. The effect of Bcp0002 binding is currently unknown [20]. 
Version définitive du manuscrit publiée dans / Final version of the manuscript published in :

\section{Journal of Proteomics (2016), Vol. 146, p. 25-33, DOI: 10.1.016/ị.jprot.201.6.06.022}

\section{Journal homepage : www.elsevier.com/locateljprot}

With the emergence of "global systems biology" tools (mainly DNA microarrays), cryptic prophages have gradually gained attention, as part of host physiology, especially under stress conditions [21]. Our goal here was to understand the importance of the effect of pBClin15 on B. cereus physiology under normal growth conditions. For this, bacteria were grown in $\mathrm{pH}$-regulated batch cultures under fully oxic conditions. We designed a high-throughput shotgun proteomic approach to decipher the interaction of pBClin15 with its host. Hierarchical clustering analysis of the proteomic data identified the altered biological processes, according to the metabolic data, and the empirical Bayes approach identified the main regulators responsible for the changes in the phenotypes. Strikingly, we determined that pBClin15 has a beneficial impact on $B$. cereus physiology. This probably helps these bacteria to cope with adverse environments.

\section{Materials and methods}

\subsection{Bacterial strains and growth conditions}

The $B$. cereus strain used in this study was the reference strain, ATCC 14579 [12]. This strain was cured of pBClin 15 as described by Voros et al. [21], resulting in the $\triangle \mathrm{pBClin} 15$ strain. $B$. cereus strains (with and without $\mathrm{pBClin} 15$ ) were cultured in batches (three independent cultivations per strain) at $\mathrm{pO}_{2}=100 \%$ [22] in minimal MOD medium supplemented with $30 \mathrm{mM}$ glucose as the carbon source [23]. Each batch culture was inoculated with an overnight subculture at an initial optical density at $600 \mathrm{~nm}\left(\mathrm{OD}_{600 \mathrm{~nm}}\right)$ of 0.02 . Aerobic batch cultures were performed at $37^{\circ} \mathrm{C}$ in a 3-liter bioreactor (BioFlo®/CelliGen ${ }^{\circledR} 115$, New Brunswick), with a working volume of 21 . The $\mathrm{pH}$ was maintained at a controlled value of 7.2 by automatic addition of $5 \mathrm{M} \mathrm{KOH}$. B. cereus growth was monitored spectrophotometrically at $600 \mathrm{~nm}$.

\subsection{Cellular and exoproteome extraction and metabolite assays}

The cells were harvested by centrifugation at the early exponential (EE), late exponential (LE) and stationary (S) growth phases for each of the bioreactor cultures and stored frozen at $-80^{\circ} \mathrm{C}$ until analysis. Soluble cellular proteins were extracted as previously described [24]. The extracellular proteins were obtained by trichloroacetic acid precipitation as described in [22]. The protein concentration was determined by the Bradford protein assay after TCA precipitation. Enzymatic test kits from Roche (Meylan, France) were used to measure glucose, lactate, ethanol, formate, acetate, and succinate concentrations in the supernatants.

\subsection{Proteolysis and shotgun tandem mass spectrometry}

Protein samples were loaded onto NuPAGE 4-12\% Bis-Tris gels (Invitrogen) for a short (about $3 \mathrm{~mm}$ ) electrophoretic migration in denaturing conditions. For each protein sample, the whole content was extracted as a single polyacrylamide band. The bands were subjected to proteolysis with sequencing grade trypsin (Roche) using 0.01\% ProteaseMAX surfactant (Promega) as previously described [25,26]. The resulting peptides were analyzed by nanoLC-MS/MS using an LTQ-Orbitrap XL hybrid mass spectrometer (ThermoFisher) coupled to an Ultimate 3000 nRSLC system (Dionex, ThermoFisher). The experimental set-up and conditions were as described [22,27]. Briefly, peptide digests were desalted on-line on a reverse-phase precolumn (Acclaim PepMap $100 \mathrm{C} 18,5 \mu \mathrm{m}$ bead size, 100-Å pore size, $300 \mu \mathrm{m}$ i.d. $\times 5 \mathrm{~mm}$, Dionex ThermoFisher). The peptides from the extracellular digests were then resolved on a nanoscale C18 PepMap $100^{\mathrm{TM}}$ capillary column ( $3 \mu \mathrm{m}$ bead size, 100-Å pore size, $75 \mu \mathrm{m}$ i.d., $15 \mathrm{~cm}$ length, LC Packings, ThermoFisher) using a 90 -min gradient. The peptides from cellular digests were resolved with the same column but $50 \mathrm{~cm}$ long using a 180-min gradient. In both cases, the gradient was from 4 to $40 \%$ solvent $\mathrm{B}\left(0.01 \% \mathrm{HCOOH}, 100 \% \mathrm{CH}_{3} \mathrm{CN}\right)$ with solvent A being $0.01 \% \mathrm{HCOOH}, 100 \% \mathrm{H}_{2} \mathrm{O}$. Full-scan mass spectra were measured from $\mathrm{m} / \mathrm{z} 300$ to 1800 in data-dependent mode using the TOP3 strategy.

\subsection{MS/MS spectra assignments to peptide sequences and protein validation}

An in-house polypeptide sequence database was made of the sequences of all previously annotated proteins encoded by the B. cereus ATCC 14579 chromosome (NC_004722) and the plasmid pBClin15 (NC_004721), and 44 proteins identified by a previous proteogenomic study (see Supplementary Table 1 in Ref. [28]). This database, used to assign peptide sequences to MS/MS spectra, comprises 5299 polypeptide sequences totaling 1,464,675 amino acids. The MASCOT Daemon search engine (version 2.3.02; Matrix Science) was used for searching tryptic peptides with the following parameters: full-trypsin specificity, a mass tolerance of $5 \mathrm{ppm}$ on the parent ion and $0.5 \mathrm{Da}$ on the MS/MS, carboxyamidomethylated Cys $(+57.0215)$ as a fixed modification and oxidized methionine $(+15.9949)$ as a variable modification. The number of tolerated missed cleavages was set at 2 . All peptide matches with a score below a $p$-value of 0.05 were filtered by the IRMa 1.28 .0 parser [29]. A protein was considered validated when at least two different peptides were detected when considering all the samples. The falsepositive rate for protein identification was estimated using the appropriate decoy database as below $0.1 \%$ with these parameters. The mass spectrometry proteomics data have been deposited in the ProteomeXchange Consortium (http://proteomecentral.proteomeexchange.org) via the
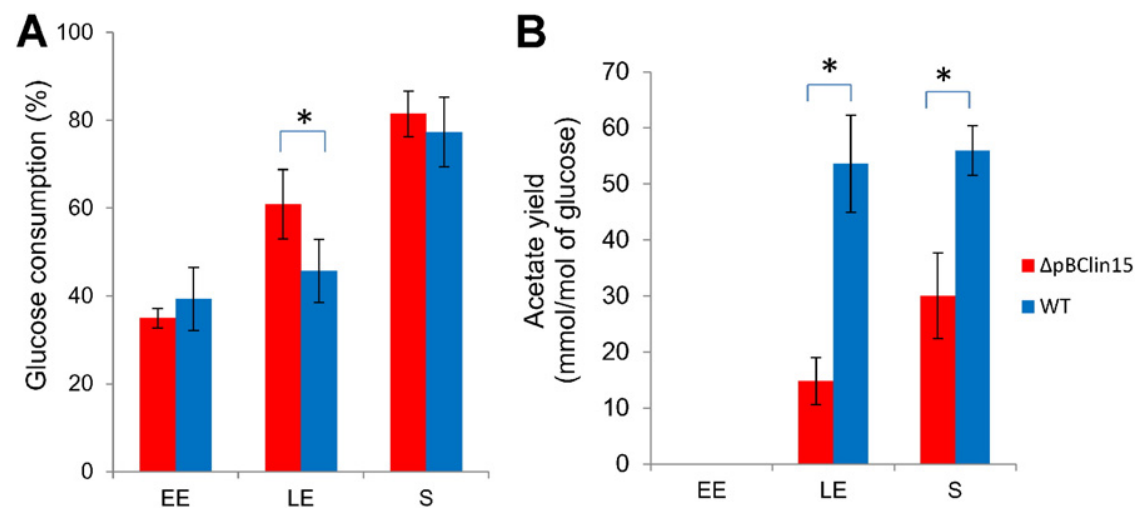

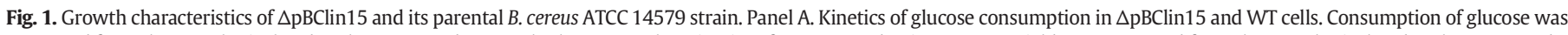

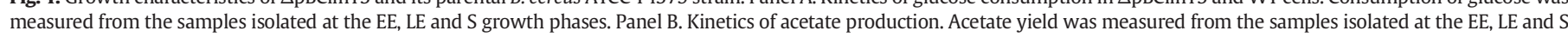
growth phases. Error bars represent the standard deviation from 3 independent measures. Significant differences $(p$-value $<0.05)$ are indicated with asterisks. 
Version définitive du manuscrit publiée dans / Final version of the manuscript published in :

Journal of Proteomics (2016), Vol. 146, p. 25-33, DOI: 10.1016/ị.jprot.2016.06.022

Journal homepage : www.elsevier.com/locateljprot

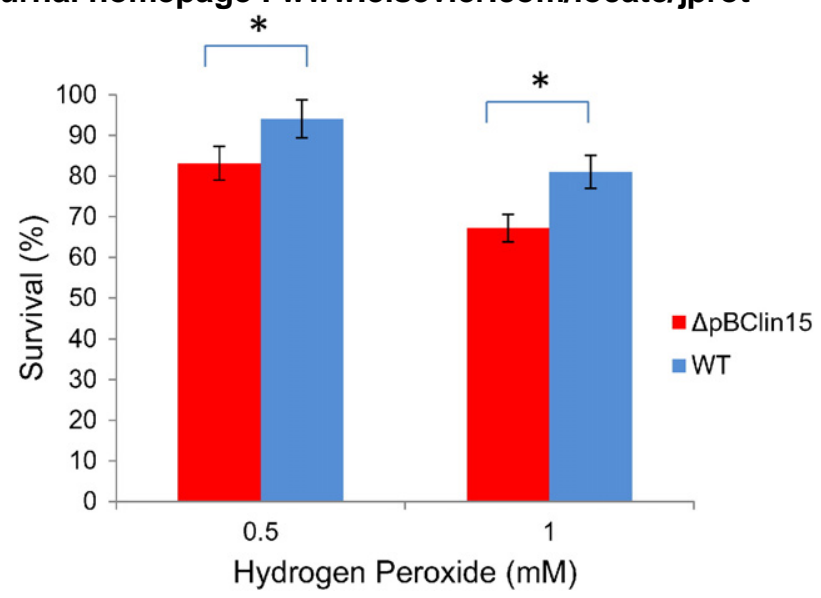

Fig. 2. Survival of $\triangle \mathrm{pBClin} 15$ and its parental B. cereus ATCC 14579 strain towards external hydrogen peroxide insult. Cells were grown in liquid culture to the mid-exponential growth phase, and subjected to 0.5 and $1 \mathrm{mM} \mathrm{H}_{2} \mathrm{O}_{2}$, respectively. Colony forming units per $\mathrm{mL}$ were counted and expressed as $(\mathrm{N} / \mathrm{N} 0) \times 100$. Error bars represent the standard deviation from 6 independent measures. Significant differences $(p$-value $<0.05)$ between $\triangle \mathrm{pBClin} 15$ and wild-type (WT) cells are indicated with asterisks.

PRIDE partner repository (http://www.ebi.ac.uk/pride) with the dataset identifiers, PXD001568, PXD002788 and PXD002789.

\subsection{Spectral count-based protein quantification and statistical analysis}

The number of MS/MS spectra per protein (spectral counts) was extracted in the 3 different nanoLC-MS/MS biological replicates for each growth phase. The normalized spectral abundance factor (NSAF) for each protein was calculated by dividing the number of spectral count (SC) by the polypeptide length (L) and by the sum of SC/L for all N proteins in the experiment [30]. Hierarchical clustering analysis (HCA) was carried out with biological replicates of each growth phase as individuals and the NSAF values assigned to functional groups as quantitative variables. The data analyses were performed with Pvclust, a package written in R (https://cran.r-project.org/bin/windows/base/old/3.2.0/) for assessing the uncertainty in HCA [31]. Pvclust provides a dendrogram that assembles all elements into a single tree with two types of p-values: Approximately Unbiases (AU) p-value, which is computed by multiscale bootstrap resampling, is a better approximation to unbiased $p$-value than Bootstrap Probability (BP) value computed by normal bootstrap resampling. One can consider that clusters (edges) with high AU values (e.g. 95\%) are strongly supported by data. A colored representation of the primary data table was carried out with the $\mathrm{R}$ package MADE4 [32] and appended to the dendrogram to indicate the nature of the computed relationship among functional groups in the table [33]. Analyses of abundance level change of proteins were performed with the LIMMA package by the LIMMA Voom method [34], a package written in $\mathrm{R}$ dedicated to linear models for microarrays. The Voom transformation was applied to the spectral counts of each protein. After this transformation, the protein abundances from label-free quantitative proteomics can be analyzed as if they were microarray data, and linear modeling may apply. To determine the differential abundance factors of proteins, the trimmed mean of M-values (TMM) normalization method was applied. After Voom transformation and TMM normalization, quantitative proteomics data were analyzed by empirical Bayes moderation of the standard errors towards a common value. Results include $\left(\log _{2}\right)$ fold changes (FC), the average $\log _{2}$-abundance level for

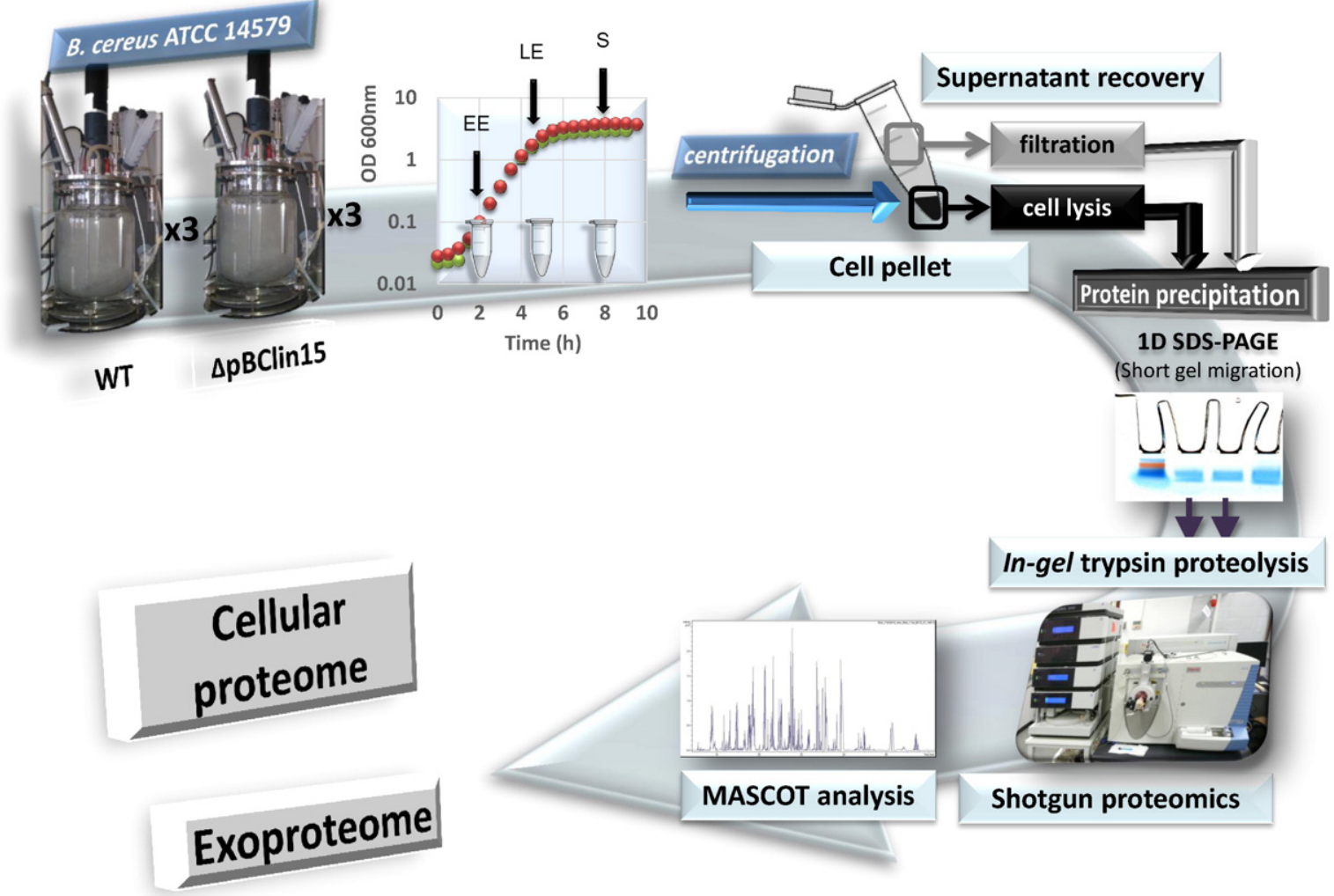

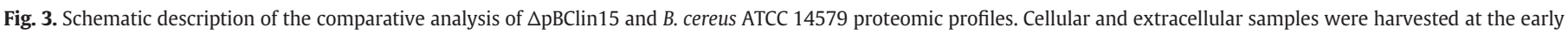

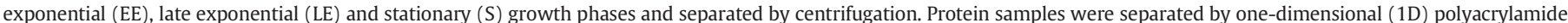

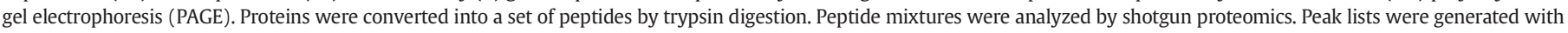

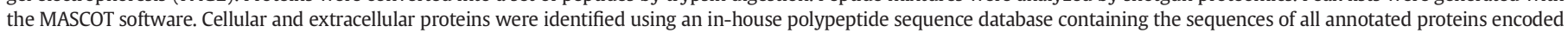
by the B. cereus chromosome (NC_004722) and pBClin15 plasmid (NC_004721). See text for further details on strategy. 
Version définitive du manuscrit publiée dans / Final version of the manuscript published in :

Journal of Proteomics (2016), Vol. 146, p. 25-33, DOI: 10.1.016/ị.jprot.201.6.06.022

Journal homepage : www.elsevier.com/locateljprot
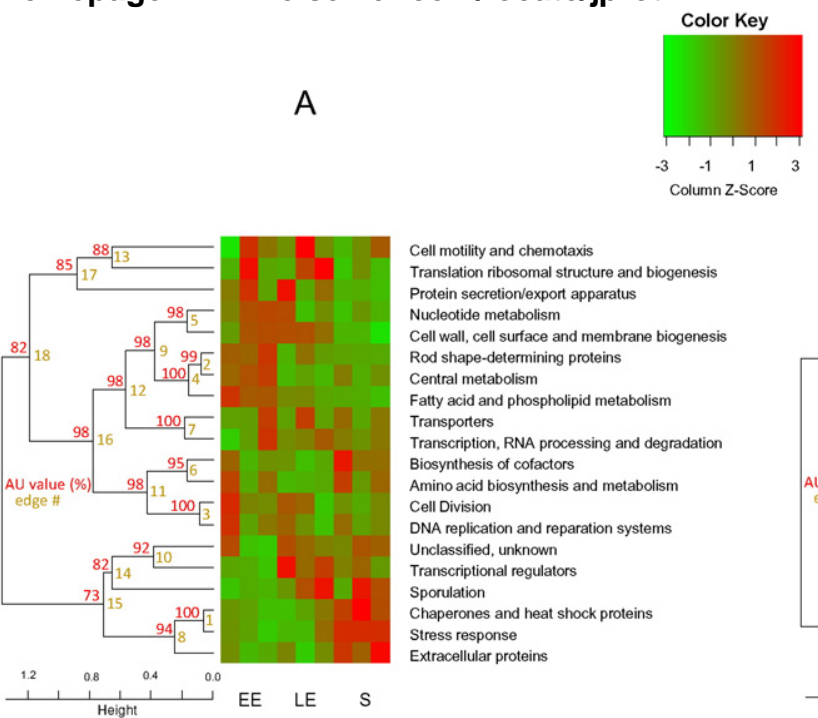

B

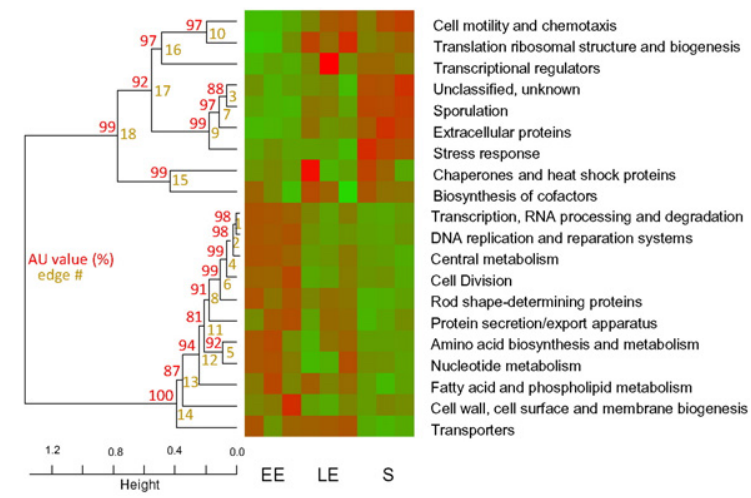

Fig. 4. Hierarchical clustering of cellular proteome dynamics based on functional group profiles. Panel A. HCA from B. cereus ATCC 14579 proteomic data. Panel B. HCA from $\triangle \mathrm{pBClin} 15$ proteomic data. Detailed composition of the 20 functional groups is given in Supplementary Table S3. The dendrograms and heat maps were constructed as described in the Material and methods. Values on the edges (clusters) of the clustering are AU $p$-values (\%). The colored scale in the heatmaps ranges from saturated green for column $z$-score -2 to saturated red for column $z$-score 2. Each functional group is represented by a single row of colored boxes. Each growth phase is represented by 3 columns, which correspond to the 3 biological replicates.

each protein across all samples, $t$-statistics, $p$-values, $p$-value adjusted for multiple testing, and $B$-statistics.

\subsection{MS signal based data analysis using MaxQuant}

The mass spectrometry raw data were processed by MaxQuant software (version 1.5.3.30) [35] using Andromeda [36] for peptide search against the in-house database of 5299 polypeptide sequences. For database searches default settings were used, with the additional options "match between run" and Label-Free Quantification (LFQ) [37] selected for the quantification purpose. The statistical analysis was performed with Perseus (version 1.5.1.2.6, standard parameters) on the logarithmized normalized ratio (base 2). Results include $\left(\log _{2}\right)$ LFQ and $t$-statistics.

\subsection{Hydrogen peroxide killing assay}

B. cereus strains (with and without pBClin15) were grown to midlog phase $\left(\mathrm{OD}_{600} \sim 0.3\right)$ in MOD medium supplemented with $30 \mathrm{mM}$ glucose. The cells were then centrifuged and resuspended in an equal volume of phosphate-buffered saline solution (PBS). Hydrogen peroxide responses were assessed by exposing samples $20 \mathrm{~min}$ to $0.5 \mathrm{mM}$ and $1 \mathrm{mM} \mathrm{H}_{2} \mathrm{O}_{2}$, respectively. Aliquots $(100 \mu \mathrm{l})$ of the samples were diluted in $\mathrm{H}_{2} \mathrm{O}$, appropriate dilutions of the culture were plated onto LB

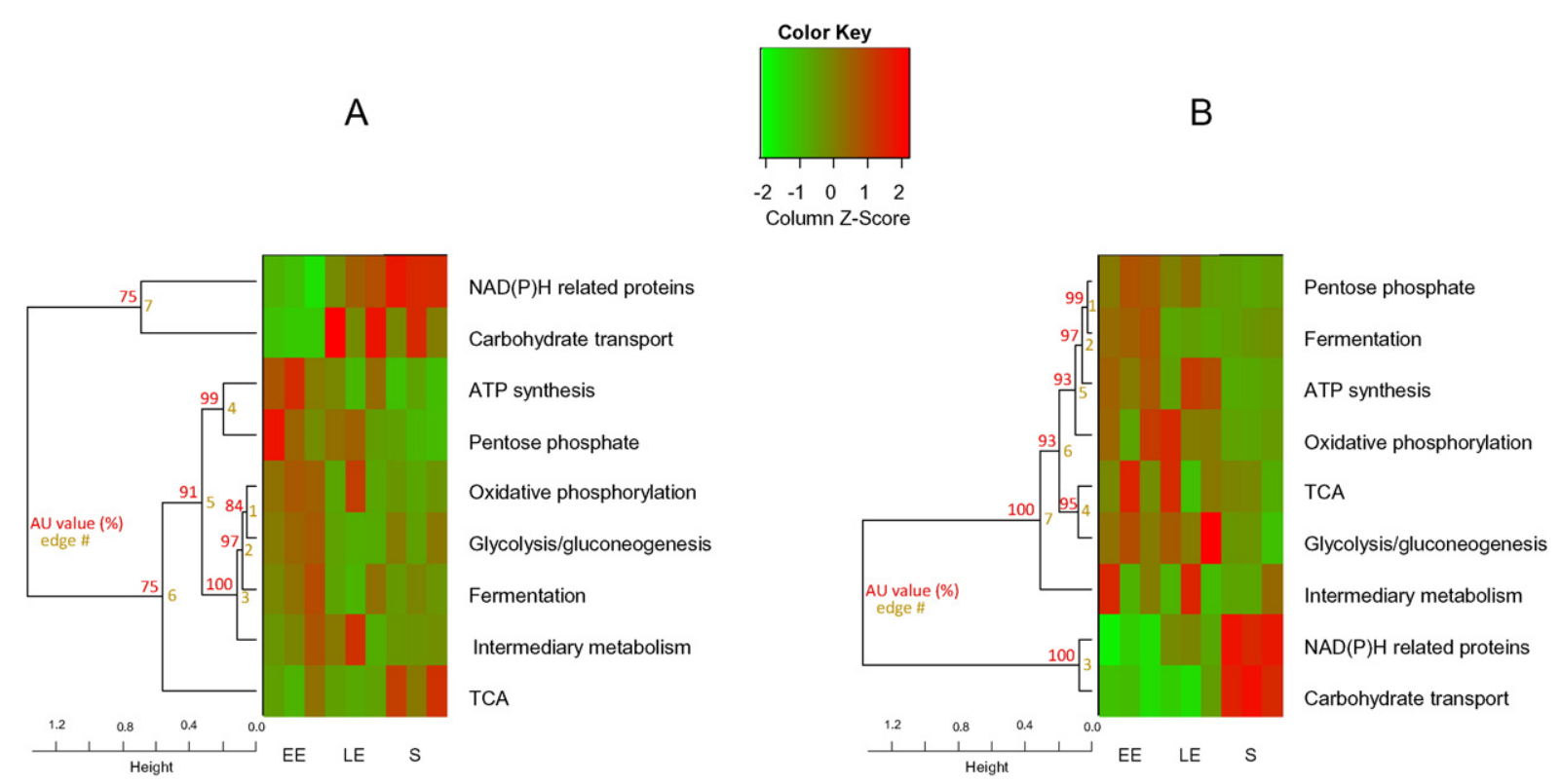

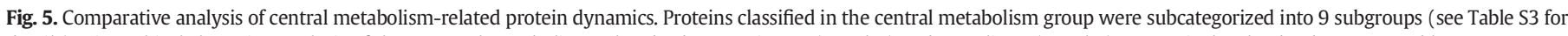

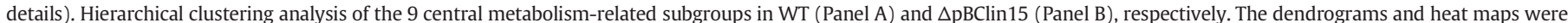

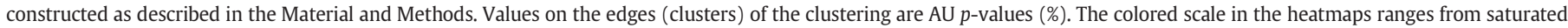

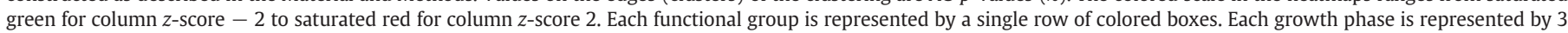
columns, which correspond to the 3 biological replicates. 


\section{Journal homepage : www.elsevier.com/locateljprot}

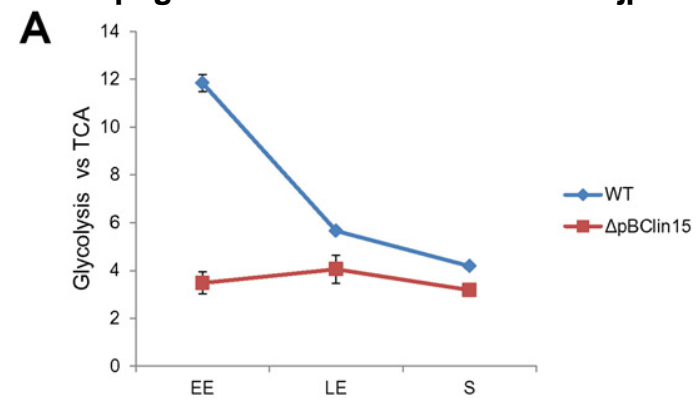

B

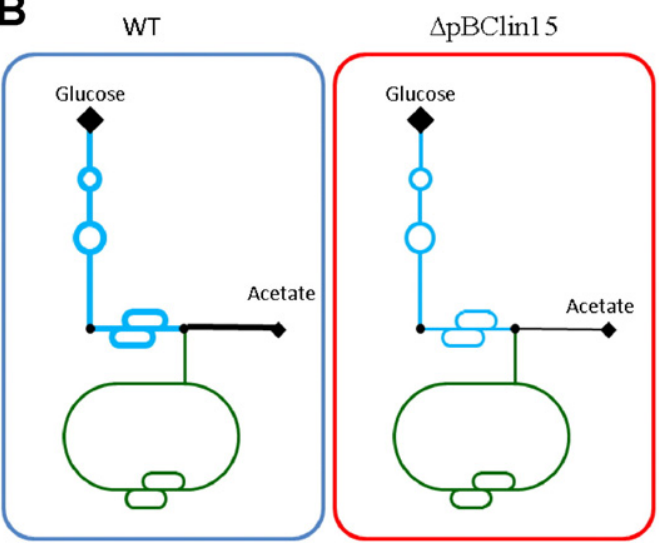

Fig. 6. Focus on glycolysis/gluconeogenesis and TCA pathways based on proteomic profiles. Panel A. Dynamics of proteins categorized in glycolysis/gluconeogenesis and TCA in B. cereus ATCC 14579 (WT) and $\triangle \mathrm{pBClin} 15$. Panel B. Simplified overviews of the main central metabolic pathways in WT and $\triangle \mathrm{pBClin} 15$. Line width and font size indicate low or high protein levels based on NSAF. Acetate excretion, which was quantified, is shown. Glycolysis is represented in blue and TCA is indicated in green.

agar, and after overnight incubation at $37^{\circ} \mathrm{C}$ the colony forming units (CFUs) were counted. All the experiments were performed at least in triplicate, and at least 2 technical replicates from each dilution step were carried out to determine the number of CFUs.

\section{Results and discussion}

3.1. Growth characteristics of the B. cereus ATCC 14579 and $\triangle p B C l i n 15$ (pBClin15-cured) strains

A pBClin15-cured B. cereus ATCC 14579 strain, named $\Delta$ pBClin15, was constructed as described by Voros et al. [21]. The removal of pBClin 15 was confirmed by $P C R$. The $\triangle \mathrm{pBClin} 15$ and wild-type strains

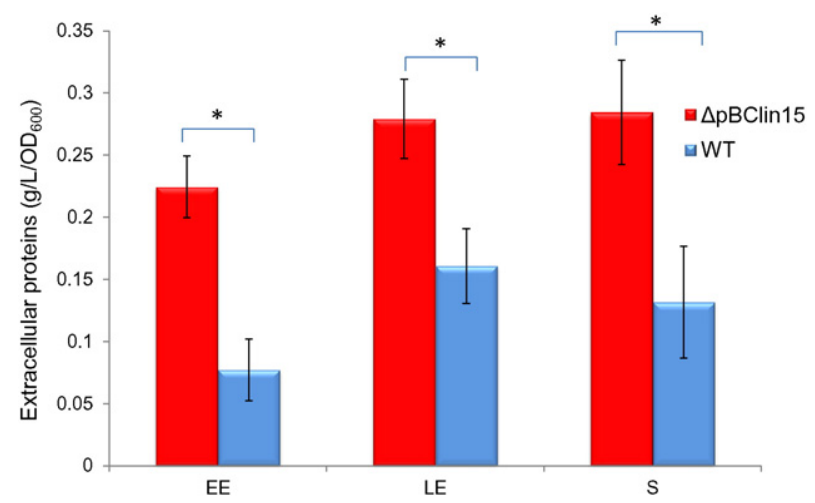

Fig. 7. Specific production of extracellular proteins by $\triangle \mathrm{pBClin} 15$ and its parental strain. Proteins were measured from culture supernatants harvested at the early exponential (EE), late exponential (LE) and stationary phases (S). Error bars represent the standard deviation from 3 independent measures. Significant differences $(p$-value $<0.05)$ between $\triangle \mathrm{pBClin} 15$ and wild-type cells are indicated with asterisks. were grown in pH-regulated batch cultures ( $\mathrm{pH} 7.2$ ) on MOD medium supplemented with $30 \mathrm{mM}$ glucose as the carbon source, under full aerobiosis $\left(\mathrm{pO}_{2}=100 \%\right)$. Supplementary Fig. 1 in Ref. [28] reports the growth curves of both strains. Despite an extended lag time $(1.9 \pm 0.2$ vs $0.6 \pm 0.6), \triangle \mathrm{pBClin} 15$ cells started exponential growth at a rate comparable to that of the wild-type $\left(\mu_{\max }=1.7 \pm 0.3 \mathrm{~h}^{-1}\right)$. However, they reached the stationary growth phase at a higher final density $\left(\mathrm{OD}_{600 \mathrm{~nm}}=3.8 \pm 0.4\right)$ than the wild-type cells $\left(\mathrm{OD}_{600 \mathrm{~nm}}=2.9 \pm\right.$ 0.0 ). These observations suggest that $\triangle \mathrm{pBClin} 15$ had a growth advantage over the wild-type strain; in other words pBClin15 placed some burden on its host. During aerobic respiratory growth, acetate is the major by-product of glucose catabolism in B. cereus [23]. Fig. 1A and B show the kinetics of glucose consumption and acetate excretion, respectively, during growth. $\triangle \mathrm{pBClin} 15$ consumed higher glucose quantities than its parental strain during the exponential growth phase (Fig. 1A) and excreted less acetate (Fig. 1B). At the end of growth, $\triangle \mathrm{pBClin} 15$ and WT cells consumed a similar amount of glucose (Fig. 1A). These results indicate that glucose supported a higher glycolytic flux (glucose uptake), lower acetate overflow and higher final growth yield (in term of final biomass per mole of glucose) in $\triangle \mathrm{pBClin} 15$ than in the wildtype strain [38-40]. pBClin15 thus impacts glucose catabolism in $B$. cereus.

Perturbation of glucose catabolism modifies endogenous ROS production in aerobically grown bacteria. Increased endogenous ROS production can translate into increased killing by oxidants [41]. To evaluate the impact of pBClin 15 on $B$. cereus tolerance to oxidant, B. cereus cells were exposed to hydrogen peroxide. Fig. 2 shows that $\triangle$ pBClin15 cells were more susceptible to $\mathrm{H}_{2} \mathrm{O}_{2}$ killing. Cells devoid of $\mathrm{pBClin} 15$ could thus experience more endogenous oxidative stress than wild-type cells.

\subsection{Comparative proteomics strategy \& global features}

To explore the molecular impact of pBClin 15 on its host, we analyzed the soluble total proteome as well as the proteins found in the extracellular environment of the cells, the so-called exoproteome [42]. Shotgun comparative proteomics was carried out by means of a label-free strategy on cells harvested by centrifugation on the first hand and on proteins present in the supernatants on the other. Fig. 3 shows the comparative proteomics strategy. Three biological replicated cultures were performed for wild-type and $\triangle \mathrm{pBClin} 15$ cells grown in $\mathrm{pH}$ - and $\mathrm{pO}_{2}$-controlled batch cultures. As indicated in Fig. 3, three samples were taken at the time points corresponding to the early exponential growth phase (EE), late exponential growth phase (LE), and stationary phase $(S)$. From the 18 resulting samples, all of the cellular soluble proteins and exoproteins obtained after trichloroacetic acid precipitation were processed separately by means of a standard gel-based procedure for trypsin proteolysis [43]. The 36 resulting peptide fractions corresponding to these proteomes were analyzed by high-throughput tandem mass spectrometry [25]. For the cellular proteomes, a total of $242,671 \mathrm{MS} / \mathrm{MS}$ spectra were detected. Among these, 129,791 were assigned to a peptide sequence (see Supplementary Table 2 in Ref. [28]), resulting in the identification of 8452 unique peptide sequences and the quantitative monitoring of 933 proteins certified with at least two different peptides (see Supplementary Table 3 in Ref. [28]). Regarding exoproteins, a total of 49,666 MS/MS spectra were assigned (see Supplementary Table 4 in Ref. [28]) from the 97,175 spectra recorded. In this case, a total of 377 proteins were validated with at least two different peptides and their quantities were monitored (see Supplementary Table 5 in Ref. [28]). Supplementary Tables 3 and 5 in Ref. [28] present the list of these proteins categorized into 20 and 9 functional large groups, respectively [44]. The exoproteome comprises 92 proteins that were not detected and validated in the cellular proteome. When considering both datasets, a total of 1025 proteins were validated and monitored for assessing the pBClin15-dependent changes in protein abundance. These changes based on spectral counting were tested 
Version définitive du manuscrit publiée dans / Final version of the manuscript published in :

Journal of Proteomics (2016), Vol. 146, p. 25-33, DOI: 10.1.016/ị.jprot.201.6.06.022

\section{Journal homepage : www.elsevier.com/locate/jprot}

statistically by empirical Bayes moderation of the analyzed standard errors towards a common value with the LIMMA R package [45]. They are presented in Supplementary Tables 6 and 7 in Ref. [28] as $\log _{2}$ of the ratio of protein abundance in $\triangle \mathrm{pBClin} 15$ relative to that measured for the wild-type cells.

\subsection{Detailed analysis of the whole cell proteome}

We first examined the group behavior of cellular proteins during growth. Cellular proteins were categorized into 20 functional groups that define the principal biological processes encoded by the $B$. cereus ATCC 14579 genome $[12,44]$. HCA was carried out to cluster functional groups with similar time-course dynamics in wild-type and $\triangle \mathrm{pBClin} 15$. The results of HCA are displayed as dendrograms, together with the ordered heat maps that reflect the original experimental observations (Fig. 4). Fig. 4 shows a strong difference in the clustering of functional groups in WT (Fig. 4A) and $\triangle \mathrm{pBClin} 15$ (Fig. 4B). This indicates that pBClin15 modulates the dynamics of biological processes at the proteome level. Specifically, the dendrograms show a higher partitioning of functional groups in WT compared to $\triangle \mathrm{pBClin} 15$, suggesting that pBClin15 may increase the propensity of the primary metabolism network to organize into nearly-independent regulation units [46]. This probably allows bacteria to use nutrients more efficiently and conserve energy to adapt to starvation conditions such as those encountered at the end of growth. Adaptation to starvation conditions involves a wide array of regulatory responses, requires high-level synthesis of proteins related to detoxification and repair systems (e.g., stress), is accompanied by a higher rate of synthesis of extracellular proteins and precedes sporulation. All of these biological processes are closely associated in $\triangle \mathrm{pBClin} 15$ (edge 18 in Fig. 4B).

We then focused on central metabolism, which provides energy, cofactor regeneration and building blocks (nucleic acids and amino acids) for biomass synthesis and controls the extent and nature of extracellular protein expression. We subdivided the central metabolism functional group into 9 subgroups and conducted a second HCA analysis. Fig. 5 shows a breakdown of the central metabolism groups into 7 edges, which are differentially partitioned and formed in the two strains. This indicates a significant impact of pBClin15 on different pathways of central metabolism during growth. Specifically, HCA clustered glycolysis/ gluconeogenesis group proteins with TCA group proteins (edge 4) with an $A U p$-value of $95 \%$ in $\triangle \mathrm{pBClin} 15$ (Fig. $5 \mathrm{~B}$ ). This indicates that the time-course dynamics of glycolytic/gluconeogenesis and TCA group proteins were similar in $\triangle \mathrm{pBClin} 15$. Interestingly, we noted that $\Delta$ pBClin15 sustained a lower level of glycolytic/gluconeogenesis

Table 1

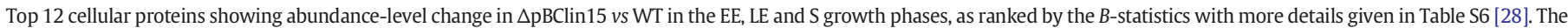
results from quantification based on MS signal analysis by MaxQuant software are given for these proteins in the last two columns.

\begin{tabular}{|c|c|c|c|c|c|c|c|c|c|}
\hline \multirow[t]{3}{*}{ Growth phase } & \multirow[t]{3}{*}{ Name } & \multirow[t]{3}{*}{ Protein } & \multirow[t]{3}{*}{ Gene } & \multirow[t]{3}{*}{ Functional annotation } & \multicolumn{3}{|c|}{ Spectral count } & \multicolumn{2}{|c|}{ MS signal } \\
\hline & & & & & \multirow[t]{2}{*}{$\log _{2} \mathrm{FC}^{\mathrm{a}}$} & \multirow{2}{*}{$\frac{\text { Adj. }^{\mathrm{b}}}{p \text {-value }}$} & \multirow[t]{2}{*}{$B^{\mathrm{c}}$} & \multirow{2}{*}{$\begin{array}{l}\log _{2} \\
\text { LFQ }^{d}\end{array}$} & \multirow{2}{*}{$\begin{array}{l}t \text {-test } \\
\text { Significance }\end{array}$} \\
\hline & & & & & & & & & \\
\hline & BCp0002 & NP_829890 & BCp0002 & pBClin15 encoded protein & -6.95 & $2.00 \mathrm{E}-22$ & 46.12 & -8.31 & + \\
\hline \multirow[t]{11}{*}{ EE } & RpoC & NP_830004 & ВC0123 & DNA-directed RNA polymerase subunit $\beta$ ' & 6.18 & $4.42 \mathrm{E}-11$ & 20.04 & 3.52 & + \\
\hline & RpoB & NP_830003 & BC0122 & DNA-directed RNA polymerase subunit $\beta$ & 5.74 & 8.07E-10 & 16.91 & 4.03 & + \\
\hline & Tpx & NP_834345 & BC4639 & Thiol peroxidase & -4.47 & 4.90E-07 & 10.53 & -3.14 & + \\
\hline & TegA & NP_835080 & BC5419 & $\begin{array}{l}\text { Acetylglucosaminyldiphosphoundecaprenol } \\
\mathrm{N} \text {-acetyl-beta-D-mannosaminyltransferase }\end{array}$ & -4.5 & $4.90 \mathrm{E}-07$ & 10.42 & -2.92 & + \\
\hline & BC4791 & NP_834493 & BC4791 & Carbonic anhydrase & -4.61 & $7.92 \mathrm{E}-07$ & 9.79 & -2.99 & + \\
\hline & FusA & NP_830008 & BC0128 & Elongation factor $\mathrm{G}$ & 4.18 & $1.20 \mathrm{E}-06$ & 9.27 & 3.08 & + \\
\hline & Tig & NP_834192 & BC4480 & Trigger factor & 4.94 & 2.77E-06 & 8.31 & 2.95 & + \\
\hline & DeaD2 & NP_830127 & BC0259 & ATP-dependent RNA helicase & 4.88 & 2.95E-06 & 8.14 & 3.77 & + \\
\hline & BC4157 & NP_833872 & BC4157 & Branched-chain alpha-keto acid dehydrogenase subunit E2 & 4.77 & 3.79E-06 & 7.75 & 3.23 & + \\
\hline & AspS & NP_834109 & BC4397 & Aspartyl-tRNA synthetase & 4.7 & 3.79E-06 & 7.64 & 2.19 & + \\
\hline & Apt & NP_834114 & BC4402 & Adenine phosphoribosyltransferase & -4.25 & 3.79E-06 & 7.6 & -1.60 & + \\
\hline \multirow[t]{12}{*}{ LE } & ВСр0002 & NP_829890 & BCp0002 & pBClin15 encoded protein & -6.9 & $1.56 \mathrm{E}-06$ & 11.49 & -9.42 & + \\
\hline & SufB & NP_834650 & BC4979 & $\mathrm{ABC}$ transporter-associated protein & 5.96 & $2.56 \mathrm{E}-05$ & 8.41 & 6.54 & + \\
\hline & BC1376 & NP_831157 & BC1376 & Flavodoxin & -5.6 & $2.56 \mathrm{E}-05$ & 8.15 & -4.35 & + \\
\hline & ClpX & NP_834191 & BC4479 & ATP-dependent protease & 5.24 & $3.60 \mathrm{E}-05$ & 7.53 & 4.59 & + \\
\hline & RrpsA & NP_831277 & BC1498 & 30 S ribosomal protein $\mathrm{S} 1$ & 5.23 & 4.12E-05 & 7.16 & 4.04 & + \\
\hline & ВС3898 & NP_833618 & ВС3898 & Integral membrane protein & -4.94 & 4.12E-05 & 7.02 & -3.39 & + \\
\hline & BC4157 & NP_833872 & BC4157 & Branched-chain alpha-keto acid dehydrogenase subunit E2 & 5.72 & 4.12E-05 & 6.95 & 6.70 & + \\
\hline & PurL & NP_830168 & ВС0329 & Phosphoribosylformylglycinamidine synthase II & 5.54 & $4.83 \mathrm{E}-05$ & 6.67 & 5.39 & + \\
\hline & GlmS & NP_830058 & ВС0190 & D-Fructose-6-phosphate amidotransferase & 5.17 & $6.99 \mathrm{E}-05$ & 6.01 & 6.32 & + \\
\hline & RocA & NP_830183 & ВС0344 & 1-Pyrroline-5-carboxylate dehydrogenase & 5.69 & $6.99 \mathrm{E}-05$ & 5.96 & 5.57 & + \\
\hline & CutC & NP_832817 & ВС3071 & Copper homeostasis protein & -4.64 & 6.99E-05 & 5.91 & -3.69 & + \\
\hline & DacC & NP_829918 & ВС0014 & D-Alanyl-D-alanine carboxypeptidase & 4.57 & $6.99 \mathrm{E}-05$ & 5.84 & 5.15 & + \\
\hline \multirow[t]{12}{*}{ S } & ВСр0002 & NP_829890 & ВСр0002 & pBClin15 encoded protein & -7.49 & $1.12 \mathrm{E}-03$ & 5.47 & -10.49 & + \\
\hline & FlaB & NP_831435 & BC1658 & Flagellin & 3.3 & $1.77 \mathrm{E}-02$ & 2.55 & 1.03 & + \\
\hline & RpmJ & NP_830034 & BC0155 & 50S Ribosomal protein L36 & -3.24 & 1.77E-02 & 2.05 & 1.02 & + \\
\hline & BC3312 & NP_833051 & ВС3312 & 3-Oxoadipate enol-lactonase & 3.19 & $1.77 \mathrm{E}-02$ & 1.99 & 1.17 & + \\
\hline & BC2311 & NP_832074 & BC2311 & 4'-Phosphopantetheinyl transferase & -3.99 & 3.79E-02 & 0.87 & -1.85 & + \\
\hline & FeoB & NP_830520 & BC0708 & Ferrous iron transport protein B & -1.76 & 3.79E-02 & 0.68 & -0.28 & + \\
\hline & BC4042 & NP_833760 & BC4042 & 3-Hydroxyisobutyrate dehydrogenase & -3.07 & 3.79E-02 & 0.55 & -2.37 & + \\
\hline & CwlF & NP_829909 & ВСp0021 & $\mathrm{N}$-Acetylmuramoyl-L-alanine amidase & -2.49 & 3.79E-02 & 0.38 & -3.59 & + \\
\hline & BioB & NP_833832 & BC4114 & Biotin synthase & -2.54 & 3.79E-02 & 0.36 & -3.17 & + \\
\hline & FabZ & NP_834943 & BC5280 & (3R)-Hydroxymyristoyl-ACP dehydratase & -2.32 & 3.79E-02 & 0.3 & -2.23 & + \\
\hline & PheS & NP_834267 & BC4561 & Phenylalanyl-tRNA synthetase subunit $\alpha$ & -2.32 & 3.79E-02 & 0.3 & -1.75 & + \\
\hline & CutC & NP_832817 & ВС3071 & Copper homeostasis protein & -3.85 & $3.79 \mathrm{E}-02$ & 0.21 & -1.26 & + \\
\hline
\end{tabular}

a FC: fold-change.

b Adj. $p$-value is the $p$-value adjusted for multiple testing.

c $B$-statistic (B) is the log-odds that the protein is differentially expressed.

d LFQ: Label-Free Quantification.

e $t$-test Significant: + indicates that $p$-value is below FDR (False Discovery Rate) threshold of 0.05 . 
Version définitive du manuscrit publiée dans / Final version of the manuscript published in :

Journal of Proteomics (2016), Vol. 146, p. 25-33, DOI: 10.1016/ị.jprot.2016.06.022

Journal homepage : www.elsevier.com/locateljprot

A

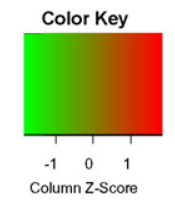

B

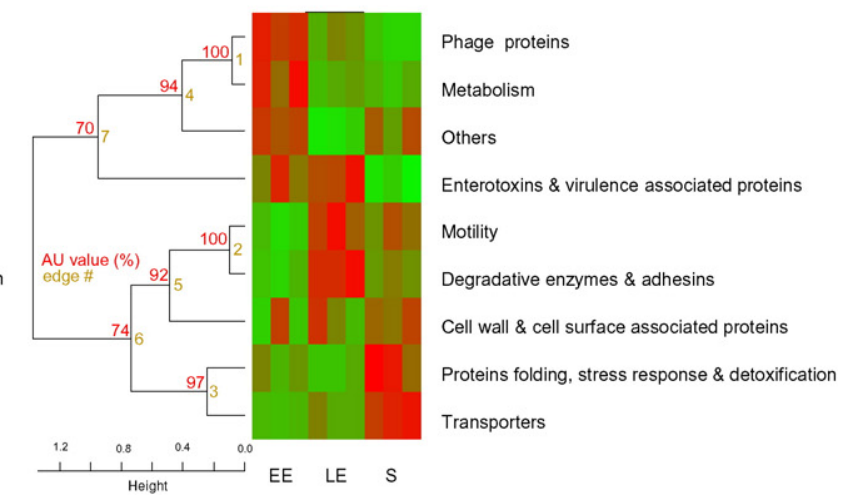

Fig. 8. Comparative analysis of exoproteome dynamics based on proteomic profile of functional groups. HCA based on 9 functional groups in $B$. cereus ATCC $14579 \mathrm{WT}$ (Panel A) and $\triangle \mathrm{pBClin} 15$ (Panel B), respectively. Detailed composition of the 9 functional groups is given in Table S5. The dendrograms and heat maps were constructed as described in the Material and Methods. Values on the edges (clusters) of the clustering are AU $p$-values (\%). The colored scale in the heatmaps ranges from saturated green for column $z$-score -2 to saturated red for column $z$-score 2 . Each functional group is represented by a single row of colored boxes. Each growth phase is represented by 3 columns, which correspond to the 3 biological replicates.

Table 2

List of exoproteins showing abundance-level change in $\triangle \mathrm{pBClin} 15 \mathrm{vs}$ WT in the EE, LE and S growth phases, as ranked by the $B$-statistics with details given in Table S7 [28]. The results from quantification based on MS signal analysis by MaxQuant software are given for these proteins in the last two columns.

\begin{tabular}{|c|c|c|c|c|c|c|c|c|c|}
\hline \multirow[b]{2}{*}{ Growth phase } & \multirow[b]{2}{*}{ Name } & \multirow[b]{2}{*}{ Protein } & \multirow[b]{2}{*}{ Gene } & \multirow[b]{2}{*}{ Functional annotation } & \multicolumn{3}{|c|}{ Spectral counts } & \multicolumn{2}{|c|}{ MS signal } \\
\hline & & & & & $\log _{2} \mathrm{FC}^{\mathrm{a}}$ & $\begin{array}{l}\text { Adj. }^{\mathrm{b}} \\
p \text {-value }\end{array}$ & $B^{c}$ & $\begin{array}{l}\log _{2} \\
\mathrm{LFQ}^{\mathrm{d}}\end{array}$ & $\begin{array}{l}t \text {-test } \\
\text { Significance }\end{array}$ \\
\hline \multirow[t]{5}{*}{$\mathrm{EE}$} & BC1894 & NP_831667 & BC1894 & Phage protein & 5.96 & 4 3E-06 & 9.9 & 9.05 & + \\
\hline & BC1893 & NP_831666 & BC1893 & Phage protein & 48 & 2.63E-04 & 52 & 7.57 & + \\
\hline & BC1862 & NP_831635 & BC1862 & Phage protein & 3.41 & $4.59 \mathrm{E}-03$ & 23 & 5.68 & + \\
\hline & BC1911 & NP_831682 & BC1911 & $\mathrm{N}$-acetylmuramoyl-L-alanine amidase & 3.5 & $1.68 \mathrm{E}-02$ & 0.65 & 6.94 & + \\
\hline & BC1901 & NP_831673 & BC1901 & Phage protein & 3.42 & $1.68 \mathrm{E}-02$ & 0.52 & 7.61 & + \\
\hline \multirow{2}{*}{ LE } & FlaA & NP_831434 & BC1657 & Flagellin & -2.56 & 7.74E-05 & 5.47 & -1.01 & + \\
\hline & FlaB & NP_831435 & BC1658 & Flagellin & 2.65 & 1.79E-02 & 0.2 & 0.31 & + \\
\hline \multirow[t]{18}{*}{$\mathrm{s}$} & ВСр0010 & NP_829898 & ВСр0010 & pBClin15 encoded protein & -5.02 & $1.02 \mathrm{E}-03$ & 4.38 & -7.11 & + \\
\hline & GlmM & NP_830056 & BC0188 & Phosphoglucosamine mutase & -4.55 & $1.02 \mathrm{E}-03$ & 4.16 & -4.16 & + \\
\hline & BC2078 & NP_831846 & BC2078 & Membrane Spanning Protein & 3.74 & 3.02E-03 & 2.58 & 0.97 & + \\
\hline & BC4985 & NP_834656 & BC4985 & $\mathrm{ABC}$ transporter substrate-binding protein & 4.5 & $3.02 \mathrm{E}-03$ & 2.48 & 1.67 & + \\
\hline & RocA & NP_830183 & ВС0344 & 1-Pyrroline-5-carboxylate dehydrogenase & -4.52 & 3.02E-03 & 2.34 & -3.06 & + \\
\hline & BC3728 & NP_833453 & ВС3728 & DNA-binding protein $\mathrm{HU}$ & 2.88 & $42 \mathrm{E}-03$ & 1.35 & 2.64 & + \\
\hline & RpmE2 & NP_834993 & BC5331 & 50S Ribosomal protein & 2.95 & $42 \mathrm{E}-03$ & 1.34 & 2.77 & + \\
\hline & Asd & NP_833521 & ВС3799 & Aspartate-semialdehyde dehydrogenase & -3.36 & $42 \mathrm{E}-03$ & 1.32 & 0.75 & + \\
\hline & DnaK & NP_834024 & BC4312 & Molecular chaperone & -4.04 & $48 \mathrm{E}-03$ & 1.26 & -4.18 & + \\
\hline & Rpe & NP_833579 & BC3858 & Ribulose-phosphate 3-epimerase & -2.75 & 4.47E-03 & 111 & -2.48 & + \\
\hline & Prc & NP_834848 & BC5184 & Carboxyl-terminal protease & 3.31 & 4.52E-03 & 1.06 & 2.38 & + \\
\hline & TerD1 & NP_830282 & BC0443 & Tellurium resistance protein & -3.38 & 4.80E-03 & 0.93 & -1.68 & + \\
\hline & DltD & NP_832595 & BC2846 & Protein dltD precursor & 3.01 & 6.27E-03 & 0.63 & 1.79 & + \\
\hline & TrpB & NP_831021 & BC1237 & Tryptophan synthase subunit beta & -3.74 & $6.48 \mathrm{E}-03$ & 0.54 & -3.28 & + \\
\hline & FtsL & NP_833637 & ВС3917 & Cell division protein & 2.49 & $8.50 \mathrm{E}-03$ & 0.22 & 2.80 & + \\
\hline & BC4371 & NP_834083 & BC4371 & Putative FMN-dependent NADH-azoreductase 1 & 3.38 & $8.50 \mathrm{E}-03$ & 0.1 & 5.19 & + \\
\hline & VanW & NP_833266 & BC3533 & Vancomycin B-type resistance protein & 4.01 & 8.50E-03 & 0.1 & 1.80 & + \\
\hline & PtsH & NP_833767 & BC4049 & Phosphocarrier protein $\mathrm{HPr}$ & 2.91 & 8.69E-03 & 0.07 & 4.31 & + \\
\hline
\end{tabular}

a FC: fold-change.

b Adj. $p$-value is the $p$-value adjusted for multiple testing.

c $B$-statistic (B) is the log-odds that the protein is differentially expressed.

d LFQ: Label-Free Quantification.

e t-test Significant: + indicates that $p$-value is below FDR (False Discovery Rate) threshold of 0.05 . 


\section{Journal homepage : www.elsevier.com/locate/jprot}

proteins and higher level of TCA proteins than WT at EE growth phase (See Supplementary Table 3 in Ref. [28]). As a result, the ratio of glycolysis/gluconeogenesis vs TCA proteins was markedly higher in WT cells compared with $\triangle \mathrm{pBClin} 15$ cells in the EE growth phase $(\sim 2.5$-fold, Fig. $6 \mathrm{~A})$. Taken together, these data suggest that by disconnecting the regulation of glycolytic and TCA enzymes, pBClin15 does allow efficient coupling between glycolysis and TCA. This probably leads to higher acetate accumulation in wild-type cells, as illustrated in Fig. 6B [47,48]. Production of acetate wastes carbon that might otherwise be directed towards protein synthesis through TCA intermediates. Proteins are either used for biomass synthesis or exported. To determine whether $\triangle \mathrm{pBClin} 15$ produced higher levels of extracellular proteins, we measured the concentration of proteins in cell supernatants. Fig. 7 shows that $\triangle \mathrm{pBClin} 15$ produced higher levels of exoproteins than wild-type cells during growth. Biosynthesis and export of proteins require energy (ATP), which is not available for cellular oxidative damage repair systems. This could lead to a significant increase in macromolecule damage. Accordingly, we found that $\triangle \mathrm{pBClin} 15$ exhibited (i) a significant increase in lag phase, which represents the rejuvenation of bacterial life that accompanies the repair of oxidative damage [49], and (ii) a decreased tolerance to exogenous oxidant [41,50]. Finally, by increasing the modularity of central metabolic pathways, pBClin 15 may increase the ATP-dependent ability of the cell to repair the damage caused by endogenous oxidative stress during aerobic growth and increase the cell's ability to cope with additional oxidative stress.

Next, we examined the abundance-level changes of individual proteins in $\triangle \mathrm{pBClin} 15$ vs WT in each growth phase (see Supplementary Table 6 in Ref. [28]) to identify the main contributors to metabolic changes. The $B$-statistical analysis uncovered a total of 58,90 and 12 differentially expressed proteins in the EE, LE, and S growth phases, respectively ( $B$-value $>0$ ). Table 1 shows the top 12 proteins showing significant abundance level changes in the EE, LE and $S$ growth phases, as ranked by the $B$-statistics [45]. The top protein in the three growth phases is the abundant $\mathrm{pBClin} 15$-encoded protein, $\mathrm{Bcp} 0002$, which is absent in $\triangle \mathrm{pBClin} 15$, as expected. In the EE growth phase, the $\beta$ and $\beta^{\prime}$ subunits of RNA polymerase (RpoC and RpoB) stand out clearly from the other chromosome-encoded proteins both in terms of $\log _{2}$ (foldchange) and $B$-value $\left(\log _{2}>5\right.$ and $B$-value $\left.>16\right)$ and in terms of $\log _{2}$ (Label-Free quantification) (Table 1). An increase in their abundance level in $\triangle \mathrm{pBClin} 15$ compared to WT probably increased RNA polymerase availability. This may contribute to the deregulation of growth at the expense of maintenance and damage protection [51,52]. In the LE and $\mathrm{S}$ growth phases, the $B$-statistics did not clearly separate the top proteins from the others (Table 1). However, LE sustained higher abundance-level change than the $S$ growth phase, both in terms of number of proteins and fold-changes. Interestingly, we noted that the complete list of differentially expressed proteins in LE (See Supplementary Table 6 in Ref. [28]) includes the LexA repressor, which was downregulated $\left(\log _{2} \mathrm{FC}=-3.9, B\right.$-value $\left.=3.73\right)$ in $\triangle \mathrm{pBClin} 15$, the catabolite control protein $\mathrm{A}(\mathrm{CcpA})$, which was upregulated $\left(\log _{2} \mathrm{FC}=3.4, B\right.$-value $=$ $2.72)$ and the transcriptional regulator, Ten $A\left(\log _{2} \mathrm{FC}=-3.9, B\right.$ value $=0.79$ ). LexA represses the SOS response to DNA damage and regulates the lytic switch in the Bacillus thuriengensis temperate phage, GIL01 [19]. CcpA plays a major role in the coordinated regulation of catabolism and anabolism to ensure optimum cell propagation [53]. It also plays a key role in toxin gene expression and virulence [54]. TenA regulates the production of extracellular proteases in Bacillus subtilis [55]. Therefore, regulatory changes induced by pBClin 15 may occur mainly at the transcriptional level through RNA polymerase availability during growth and several regulatory circuits at the end of growth.

\subsection{Detailed analysis of the exoproteome}

We showed that pBClin15 restricted the production of extracellular proteins, in terms of quantities. To determine whether pBClin15 also modulated the composition of the $B$. cereus exoproteome, we first compared the group behavior of exoproteins in $\triangle \mathrm{pBClin} 15$ and its parental strain during growth. Fig. 8 (Panels A and B) shows that pBClin15 influences the hierarchical organization of functional groups during growth. Interestingly, the dendrograms revealed that (i) the dynamics of metabolism group proteins is very similar to the dynamics of phage group proteins in $\triangle$ pBClin 15 (edge $1, \mathrm{AU} p$-value $=100 \%$, Fig. $8 \mathrm{~B}$ ), while it was very similar to the dynamics of the folding, stress response and detoxification group proteins in WT (edge 1 , AU $p$-value $=100 \%$, Fig. $8 \mathrm{~A}$ ); this suggests a disorganization of the intracellular metabolism in pBClin15 [22], (ii) the enterotoxin/virulence-associated protein group is in the immediate vicinity of the motility and to a lesser extent the degradative enzyme \& adhesins group in WT (Fig. 8A), while it was far from these groups in pBClin15 (Fig. 8B); this suggests a less efficient coordination of virulence factor secretion in $\triangle \mathrm{pBClin} 15$. Comparison of heatmaps reveals a coordinate enrichment of metabolism and phage proteins in the EE growth phase compared with the LE and S growth phases in $\triangle \mathrm{pBClin} 15$. Table 2 shows that the enrichment in phage proteins in EE was mainly due to the overexpression of 4 phage proteins of unknown function: BC1894, BC1893, BC1862, and BC1901. Table 2 also shows that in the EE growth phase, the pBClin15-encoded protein, Bcp0002, was at the top of the list as ranked by the $B$-statistics and was downregulated in the $\triangle \mathrm{pBClin} 15$ exoproteome as in the cellular proteome. In the LE growth phase, the top protein in terms of fold-change and $B$-value was the cold-shock protein, CspB. Interestingly, CspB shows some sequence similarities with Bcp0002 [20]. The $S$ growth phase supports the largest list of differentially expressed proteins with, at the top of the list, the pBClin15-encoded protein, Bcp0010, which is downregulated as expected. Taken together these data suggest that $\mathrm{pBClin} 15$ influences the dynamics of the $B$. cereus exoproteome by restricting the production of chromosome-encoded phage proteins through cellular regulatory circuits.

\section{Conclusion}

To our knowledge, this paper reports the first proteomic approach to deciphering the interaction between a cryptic prophage and its host under normal growth conditions. Our results demonstrate the beneficial impact of pBClin15 on B. cereus metabolism during respiratory aerobic growth. Intricate regulatory networks, including positive or negative regulation by transcriptional regulators and RNA polymerase regulation, may explain the dynamic nature of the pBClin15 interaction with its host. The pBClin15-encoded DNA-binding protein, Bcp0002, which was expressed constitutively during growth, may play an important role in this regulatory network, which needs to be investigated.

The beneficial impact of pBClin 15 on $B$. cereus metabolism includes protection from oxidative damage. This helps the bacteria to cope with adverse environments [21]. This may also increase genetic stability by limiting high-frequency mutations, based on the accumulation of DNA damage.

Evolutionary forces promote bacterial growth in many environmental niches, so survival and growth under difficult conditions is crucial. It is then not surprising that bacteria adapt to their environment via the acquisition of novel genes via phages. Our results show that the release of chromosome-encoded phage proteins into the extracellular milieu causes a selective disadvantage to $B$. cereus, and the introduction of pBClin 15 confers beneficial phenotypes that allow the exploitation of a competitive environment. We thus conclude that the capacity of $B$. cereus ATCC14579 to adapt to various environments arises in some cases from the acquisition of pBClin15. Finally, these data support the idea that $\mathrm{pBClin} 15$ may have a much greater role in B. cereus ecology than has hitherto been suspected.

Supplementary data to this article can be found online at http://dx. doi.org/10.1016/j.jprot.2016.06.022.

\section{Conflicts of interest}

The authors declare that there are no conflicts of interest. 


\section{Journal homepage : www.elsevier.com/locateljprot}

\section{Acknowledgements}

We thank Virginie Jouffrey for her help in proteomic data editing.

\section{References}

[1] M.H. Guinebretiere, S. Auger, N. Galleron, M. Contzen, B. De Sarrau, M.L. De Buyser et al., Bacillus cytotoxicus sp. nov. is a novel thermotolerant species of the Bacillus cereus group occasionally associated with food poisoning, Int. J. Syst. Evol. Microbiol. 63 (2013) 31-40.

[2] G. Jimenez, M. Urdiain, A. Cifuentes, A. Lopez-Lopez, A.R. Blanch, J. Tamames, et al., Description of Bacillus toyonensis sp. nov., a novel species of the Bacillus cereus group, and pairwise genome comparisons of the species of the group by means of ANI calculations, Syst. Appl. Microbiol. 36 (2013) 383-391.

[3] J. Zheng, Z. Guan, S. Cao, D. Peng, L. Ruan, D. Jiang, et al., Plasmids are vectors for redundant chromosomal genes in the Bacillus cereus group, BMC Genomics 16 (2015) 6.

[4] D.A. Rasko, M.J. Rosovitz, O.A. Okstad, D.E. Fouts, L. Jiang, R.Z. Cer, et al., Complete sequence analysis of novel plasmids from emetic and periodontal Bacillus cereus isolates reveals a common evolutionary history among the $B$. cereus-group plasmids, including Bacillus anthracis pXO1, J. Bacteriol. 189 (2007) 52-64.

[5] M. Ehling-Schulz, B. Svensson, M.H. Guinebretiere, T. Lindback, M. Andersson, A. Schulz, et al., Emetic toxin formation of Bacillus cereus is restricted to a single evolutionary lineage of closely related strains, Microbiology 151 (2005) 183-197.

[6] T.M. Koehler, Bacillus anthracis genetics and virulence gene regulation, Curr. Top. Microbiol. Immunol. 271 (2002) 143-164.

[7] A. Aronson, Sporulation and delta-endotoxin synthesis by Bacillus thuringiensis, Cell. Mol. Life Sci. 59 (2002) 417-425.

[8] L.A. Bulla Jr., D.B. Bechtel, K.J. Kramer, Y.I. Shethna, A.I. Aronson, P.C. Fitz-James, Ultrastructure, physiology, and biochemistry of Bacillus thuringiensis, Crit. Rev. Microbiol. 8 (1980) 147-204.

[9] H.R. Whiteley, H.E. Schnepf, The molecular biology of parasporal crystal body formation in Bacillus thuringiensis, Annu. Rev. Microbiol. 40 (1986) 549-576.

[10] S. Guo, M. Liu, D. Peng, S. Ji, P. Wang, Z. Yu, et al., New strategy for isolating novel nematicidal crystal protein genes from Bacillus thuringiensis strain YBT-1518, Appl. Environ. Microbiol. 74 (2008) 6997-7001.

[11] C.R. Carlson, T. Johansen, A.B. Kolsto, The chromosome map of Bacillus thuringiensis subsp. Canadensis HD224 is highly similar to that of the Bacillus cereus type strain ATCC 14579, FEMS Microbiol. Lett. 141 (1996) 163-167.

[12] N. Ivanova, A. Sorokin, I. Anderson, N. Galleron, B. Candelon, V. Kapatral, et al., Genome sequence of Bacillus cereus and comparative analysis with Bacillus anthracis, Nature 423 (2003) 87-91.

[13] C. Verheust, N. Fornelos, J. Mahillon, GIL16, a new gram-positive tectiviral phage related to the Bacillus thuringiensis GIL01 and the Bacillus cereus pBClin15 elements, J. Bacteriol. 187 (2005) 1966-1973.

[14] H.W. Ackermann, W.A. Smirnoff, Study of lysogeny in Bacillus thuringiensis and B. cereus, Can. J. Microbiol. 24 (1978) 818-826.

[15] K.A. Bishop-Lilly, R.D. Plaut, P.E. Chen, A. Akmal, K.M. Willner, A. Butani, et al., Whole genome sequencing of phage resistant Bacillus anthracis mutants reveals an essential role for cell surface anchoring protein CsaB in phage AP50c adsorption, Virol. J. 9 (2012) 246.

[16] S. Sozhamannan, M. McKinstry, S.M. Lentz, M. Jalasvuori, F. McAfee, A. Smith, et al., Molecular characterization of a variant of Bacillus anthracis-specific phage AP50 with improved bacteriolytic activity, Appl. Environ. Microbiol. 74 (2008) 6792-6796.

[17] N.J. Stromsten, S.D. Benson, R.M. Burnett, D.H. Bamford, J.K. Bamford, The Bacillus thuringiensis linear double-stranded DNA phage Bam35, which is highly similar to the Bacillus cereus linear plasmid pBClin15, has a prophage state, J. Bacteriol. 185 (2003) 6985-6989.

[18] C. Verheust, G. Jensen, J. Mahillon, pGIL01, a linear tectiviral plasmid prophage originating from Bacillus thuringiensis serovar israelensis, Microbiology 149 (2003) 2083-2092.

[19] N. Fornelos, J.K. Bamford, J. Mahillon, Phage-borne factors and host LexA regulate the lytic switch in phage GIL01, J. Bacteriol. 193 (2011) 6008-6019.

[20] F.B. Stabell, W. Egge-Jacobsen, P.A. Risoen, A.B. Kolsto, O.A. Okstad, ORF 2 from the Bacillus cereus linear plasmid pBClin15 encodes a DNA binding protein, Lett. Appl. Microbiol. 48 (2009) 51-57.

[21] A. Voros, R. Simm, J.K. Kroeger, A.B. Kolsto, Gene transcription from the linear plasmid pBClin15 leads to cell lysis and extracellular DNA-dependent aggregation of $\mathrm{Ba}$ cillus cereus ATCC 14579 in response to quinolone-induced stress, Microbiology 159 (2013) 2283-2293.

[22] J.P. Madeira, B. Alpha-Bazin, J. Armengaud, C. Duport, Time dynamics of the Bacillus cereus exoproteome are shaped by cellular oxidation, Front. Microbiol. 6 (2015) 342

[23] E. Rosenfeld, C. Duport, A. Zigha, P. Schmitt, Characterization of aerobic and anaerobic vegetative growth of the food-borne pathogen Bacillus cereus F4430/73 strain, Can. J. Microbiol. 51 (2005) 149-158.

[24] G. Clair, J. Armengaud, C. Duport, Restricting fermentative potential by proteome remodeling: an adaptative strategy evidenced in Bacillus cereus, Mol. Cell Proteomics 11 (2012), M111 013102

[25] G. Clair, S. Roussi, J. Armengaud, C. Duport, Expanding the known repertoire of virulence factors produced by Bacillus cereus through early secretome profiling in three redox conditions, Mol. Cell. Proteomics 9 (2010) 1486-1498.
[26] A. de Groot, R. Dulermo, P. Ortet, L. Blanchard, P. Guerin, B. Fernandez, et al., Alliance of proteomics and genomics to unravel the specificities of Sahara bacterium Deinococcus deserti, PLoS Genet. 5 (2009), e1000434.

[27] A. Dedieu, J.C. Gaillard, T. Pourcher, E. Darrouzet, J. Armengaud, Revisiting iodination sites in thyroglobulin with an organ-oriented shotgun strategy, J. Biol. Chem. 286 (2011) 259-269.

[28] J.P. Madeira, H. Omer, B. Alpha-Bazin, J. Armengaud, C. Duport, Cellular and Exoproteome Dynamics of Bacillus cereus ATCC 14579 with and Without pBClin15. Data in Brief, 2016 (Submitted).

[29] V. Dupierris, C. Masselon, M. Court, S. Kieffer-Jaquinod, C. Bruley, A toolbox for validation of mass spectrometry peptides identification and generation of database: IRMa, Bioinformatics 25 (2009) 1980-1981.

[30] B.L. Zybailov, L. Florens, M.P. Washburn, Quantitative shotgun proteomics using a protease with broad specificity and normalized spectral abundance factors, Mol. BioSyst. 3 (2007) 354-360.

[31] R. Suzuki, H. Shimodaira, Pvclust: an R package for assessing the uncertainty in hierarchical clustering, Bioinformatics 22 (2006) 1540-1542.

[32] A.C. Culhane, J. Thioulouse, G. Perriere, D.G. Higgins, MADE4: an R package for multivariate analysis of gene expression data, Bioinformatics 21 (2005) 2789-2790.

[33] M.B. Eisen, P.T. Spellman, P.O. Brown, D. Botstein, Cluster analysis and display of genome-wide expression patterns, Proc. Nat. Acad. Sci. U.S.A. 95 (1998) 14863-14868.

[34] G.K. Smyth, J. Michaud, H.S. Scott, Use of within-array replicate spots for assessing differential expression in microarray experiments, Bioinformatics 21 (2005) 2067-2075.

[35] J. Cox, M. Mann, MaxQuant enables high peptide identification rates, individualized p.p.b.-range mass accuracies and proteome-wide protein quantification, Nat. Biotechnol. 26 (2008) 1367-1372.

[36] J. Cox, N. Neuhauser, A. Michalski, R.A. Scheltema, J.V. Olsen, M. Mann, Andromeda: a peptide search engine integrated into the MaxQuant environment, J. Proteome Res. 10 (2011) 1794-1805.

[37] J. Cox, M.Y. Hein, C.A. Luber, I. Paron, N. Nagaraj, M. Mann, Accurate proteome-wide label-free quantification by delayed normalization and maximal peptide ratio extraction, termed MaxLFQ, Mol. Cell. Proteomics 13 (2014) 2513-2526.

[38] S. Castano-Cerezo, J.M. Pastor, S. Renilla, V. Bernal, J.L. Iborra, M. Canovas, An insight into the role of phosphotransacetylase (pta) and the acetate/acetyl-CoA node in Escherichia coli, Microb. Cell Factories 8 (2009) 54.

[39] K. Peebo, K. Valgepea, R. Nahku, G. Riis, M. Oun, K. Adamberg, et al., Coordinated activation of PTA-ACS and TCA cycles strongly reduces overflow metabolism of acetate in Escherichia coli, Appl. Microbiol. Biotechnol. 98 (2014) 5131-5143.

[40] M.R. Sadykov, V.C. Thomas, D.D. Marshall, C.J. Wenstrom, D.E. Moormeier, T.J. Widhelm, et al., Inactivation of the Pta-AckA pathway causes cell death in Staphylococcus aureus, J. Bacteriol. 195 (2013) 3035-3044.

[41] M.P. Brynildsen, J.A. Winkler, C.S. Spina, I.C. MacDonald, J.J. Collins, Potentiating antibacterial activity by predictably enhancing endogenous microbial ROS production, Nat. Biotechnol. 31 (2013) 160-165.

[42] J. Armengaud, J.A. Christie-Oleza, G. Clair, V. Malard, C. Duport, Exoproteomics: exploring the world around biological systems, Expert Rev Proteomics. 9 (2012) 561-575.

[43] E.M. Hartmann, F. Allain, J.C. Gaillard, O. Pible, J. Armengaud, Taking the shortcut for high-throughput shotgun proteomic analysis of bacteria, Methods Mol. Biol. 1197 (2014) 275-285

[44] H. Omer, B. Alpha-Bazin, J.L. Brunet, J. Armengaud, C. Duport, Proteomics identifies Bacillus cereus EntD as a pivotal protein for the production of numerous virulence factors, Front. Microbiol. 6 (2015) 1004.

[45] S. GK, Linear models and empirical Bayes methods for assessing differential expression in microarray experiments, Stat. Appl. Genet. Mol. Biol. 3 (2004), Article3.

[46] E. Ravasz, A.L. Somera, D.A. Mongru, Z.N. Oltvai, A.L. Barabasi, Hierarchical organization of modularity in metabolic networks, Science 297 (2002) 1551-1555.

[47] A. Veit, T. Polen, V.F. Wendisch, Global gene expression analysis of glucose overflow metabolism in Escherichia coli and reduction of aerobic acetate formation, Appl. Microbiol. Biotechnol. 74 (2007) 406-421.

[48] K. Zhuang, G.N. Vemuri, R. Mahadevan, Economics of membrane occupancy and respiro-fermentation, Mol. Syst. Biol. 7 (2011) 500.

[49] M.D. Rolfe, C.J. Rice, S. Lucchini, C. Pin, A. Thompson, A.D. Cameron, et al., Lag phase is a distinct growth phase that prepares bacteria for exponential growth and involves transient metal accumulation, J. Bacteriol. 194 (2012) 686-701.

[50] K.J. Adolfsen, M.P. Brynildsen, Futile cycling increases sensitivity toward oxidative stress in Escherichia coli, Metabolic engineering. 29 (2015) 26-35.

[51] B. Gummesson, L.U. Magnusson, M. Lovmar, K. Kvint, O. Persson, M. Ballesteros, et al., Increased RNA polymerase availability directs resources towards growth at the expense of maintenance, EMBO J. 28 (2009) 2209-2219.

[52] T. Nystrom, Growth versus maintenance: a trade-off dictated by RNA polymerase availability and sigma factor competition? Mol. Microbiol. 54 (2004) 855-862.

[53] Y. Fujita, T. Satomura, S. Tojo, K. Hirooka, CcpA-mediated catabolite activation of the Bacillus subtilis ilv-leu operon and its negation by either CodY- or TnrA-mediated negative regulation, J. Bacteriol. 196 (2014) 3793-3806.

[54] C. Chiang, C. Bongiorni, M. Perego, Glucose-dependent activation of Bacillus anthracis toxin gene expression and virulence requires the carbon catabolite protein CcpA, J. Bacteriol. 193 (2011) 52-62.

[55] A.V. Toms, A.L. Haas, J.H. Park, T.P. Begley, S.E. Ealick, Structural characterization of the regulatory proteins TenA and TenI from Bacillus subtilis and identification of TenA as a thiaminase II, Biochemistry 44 (2005) 2319-2329. 